\section{Moss Pigments}

\section{An Investigation of the Occurrence of Proanthocyanidins in Mosses}

\section{GERD BENDZ, OLLE MARTENSSON and ERLING NILSSON}

Institute of Chemistry and Institute of Quantum Chemistry, University of Uppsala, Uppsala, Sweden

Tn connection with our studies of the 1 reddish pigmentation in mosses ${ }^{1-3}$ we have also investigated several species (Table 1) with regard to the occurrence of

Table 1.

Andreaea rupestris Hedw.

Anomodon viticulosus (Hedw.) Hook. et Tayl. Antitrichia curtipendula (Hedw.) Brid. Atrichum undulatum (Hedw.) P. Beauv.

Bartramia pomiformis Hedw.

Brachythecium salebrosum (Web. et Mohr) B.S.G.

Cirriphyllum piliferum (Hedw.) Grout Climacium dendroides (Hedw.) Web. et Mohr Dicranum polysetum Sw.

$$
\text { " scoparium Hedw. }
$$

Fontinalis antipyretica L. ex Hedw.

Grimmia hartmanii Schimp.

Hedwigia ciliata (Hedw.) Ehrh. ex P. Beauv. Homalia trichomanoides (Hedw.) B.S.G.

Homalothecium sericeum (Hedw.) B.S.G.

Hylocomium splendens (Hedw.) B.S.G.

Hypnum cupressiforme L. ex Hedw.

Isothecium myurum Brid.

Leskeella nervosa (Brid.) Loeske

Mnium undulatum Weis ex Hedw.

Orthothecium chryseum (Schwaegr.) B.S.G.

Paraleucobryum longifolium (Hedw.) Loeske Plagiothecium laetum B.S.G.

Pleurozium schreberi (Brid.) Mitt.

Pohlia cruda (Hedw.) Lindb.

Polytrichum commune Hedw.

Ptilium crista-castrensis (Hedw.) De Not.

Pylaisia polyantha (Hedw.) B.S.G.

Racomitrium lanuginosum (Hedw.) Brid.

Rhytidiadelphus triquetrus (Hedw.) Warnst.

Sphagnum girgensohnii Russ.

- squarrosum Pers.

Thuidium philibertii Limpr.

* Part 3, Arkiv Kemi. In press. proanthocyanidins, that is compounds which are convertible into flavylium salts by treatment with acids. With the exception of Orthothecium chryseum which has a faintly reddish tinge, the general appearance of the species chosen must be characterised as non-reddish, although in some of them structures such as the stem, the nerve and the border of the leaves had a reddish tinge. It should also be stressed that the samples consisted of the gametophyts only, i.e. they did not contain the capsules and setae.

The ground moss was treated with $2 \mathrm{~N}$ hydrochloric acid according to the method used by Bate-Smith.4 In addition most of the species listed have also been treated for several days at room temperature with methanol containing $10 \%$ conc. hydrochloric acid, a method used in a similar investigation of ferns, where proanthocyanidins seem to be rather common. After evaporation the extracts were chro. matographed in Forestal solution. An acidified alcoholic extract from Vicia faba con. taining delphinidin and cyanidin was used as reference. ${ }^{6}$ No red spots were detectable on the chromatograms of the different extracts. Even the extract from Orthothecium chryseum contained no red pig. ments, indicating that in this moss the red pigmentation is very strongly bound to the cell wall.

Three other moss species have been investigated earlier by Bate-Smith ${ }^{4}$ and found to contain no proanthocyanidins. Since the species now tested represent many different systematic groups within $M u s c i$, there is reason to suppose that mosses generally do not contain proantho. cyanidins. In this connection it should be pointed out that the anthocyanins hitherto isolated from mosses are of the uncommon luteolinidin type, i.e. they lack a hydroxy group in the 3-position. ${ }^{i}$ The absence or rare occurrence of proanthocyanidins and 3-hydroxylated anthocyanidins in mosses should then underline the suggestion by Harborne ${ }^{7}$ that the production of anthocyanidins lacking a 3-hydroxy group (luteolinidin and apigenidin) is a "primitive" character.

The material of the species investigated have been collected in Sweden except that of Orthothecium chryseum which was from Alaska. The species are listed alphabetically and the nomenclature of the specific names is that adopted by Index Muscorum (as far as they can be found in this as yet un. finished work). Most of the species are more 
or less common and have a large area of distribution.

1. Bendz, G., Mårtensson, O. and Terenius, L. Acta Chem. Scand. 16 (1962) 1183.

2. Bendz, G. and Mårtensson, O. Acta Chem. Scand. 17 (1963) 266.

3. Bendz, G., Mårtensson, $O$. and Nilsson, $\mathbf{E}$. Arkiv Kemi. In press.

4. Bate-Smith, E. C. and Lerner, N. H. Biochem. J. 58 (1954) 126.

5. Fredga, A. and Bendz, G. Ann. 691 (1966) 177.

6. Bate-Smith, E. C. Private communication.

7. Harborne, J. B. Nature 207 (1965) 984.

Received December 22, 1965.

\section{Organic Selenium Compounds}

\author{
I. Preparation of Methyl- \\ substituted Selenosemicarbazides
}

\section{K. A. JENSEN, GIDEON FELBERT, CARL TH. PEDERSEN and ULLA SVANHOLM}

\author{
Chemical Laboratory II (General and \\ Organic Chemistry), University of \\ Copenhagen, The H. C. Orsted Institute, \\ Copenhagen, Denmark
}

W ith the purpose of comparing the infra. red spectra of corresponding thiosemicarbazides and selenosemicarbazides, we have prepared several new selenosemicarbazides, expecially methyl-substituted selenosemicarbazides. There will be three monomethyl, five dimethyl, five trimethyl, three tetramethyl and one pentamethyl selenosemicarbazide, in all 17 compounds. The corresponding 17 thiosemicarbazides have all been prepared; ${ }^{1}$ however, it does not seem to be possible to prepare all selenosemicarbazides with two methyl groups in the 4-position without the use of the unknown dimethylselenocarbamoyl chloride.
In this paper, we report on the preparation of the eleven methyl-substituted selenosemicarbazides which are not disubstituted in the 4-position. Some 4,4dialkylselenosemicarbazides have been prepared from (dialkylselenocarbamoylseleno) acetic acids and will be described in a subsequent paper.

The reaction of methyl isoselenocyanate with hydrazine, methylhydrazine, 1,1-dimethylhydrazine, 1,2-dimethylhydrazine, and trimethylhydrazine, respectively, yielded 4-methylselenosemicarbazide, 2,4dimethylselenosemicarbazide, 1,1,4-trimethylselenosemicarbazide, 1,2,4-trimeth. ylselenosemicarbazide, and 1,1,2,4-tetramethylselenosemicarbazide.

The preparation of in the 4-position unsubstituted selenosemicarbazides in a similar manner as that used for thiosemicarbazides, i.e. heating of hydrazinium selenocyanates, could not be used, because extensive decomposition with the formation of selenium took place. According to the sensitive precipitation reaction with nickel salts (cf. Jensen and Frederiksen ${ }^{2}$ ) no selenosemicarbazide was formed in this reaction. However, selenosemicarbazides unsubstituted in the 4-position were obtained in a way which also had been used in our studies of thiosemicarbazides, namely by removal of a tert.-butyl group from the 4-position on boiling with concentrated hydrochloric acid. The necessary 4-tert-butylselenosemicarbazides could be prepared in excellent yields from hydra. zines and tert-butyl isoselenocyanate. Unexpectedly, the yields of selenosemicarbazides were much higher than the yields of thiosemicarbazides by the corresponding method. In this way, we succeeded in preparing 2-methylselenosemicarbazide, 1,1-dimethylselenosemicarbazide, 1,2-dimethylselenosemicarbazide, and 1,1,2-trimethylselenosemicarbazide.

The preparation of 1-methylsubstituted thiosemicarbazides had encountered unusual difficulties 1 but a method had been found which was also successful in the case of selenosemicarbazides. An alkyl isoselenocyanate is treated with 1-methyl-1-tert butyloxycarbonylhydrazine ${ }^{1}$ and the tertbutyloxycarbonyl group is subsequently removed by treatment with cold concentrated hydrochloric acid: See p. 280.

If $R$ is tert-butyl this group could be removed subsequently by treatment with hot conc. hydrochloric acid, so that 1 methylselenosemicarbazide can be pre. pared via 1-methyl-4-tert-butylselenosemi- 